\title{
Investigation of the Effects of Gasoline-Bioethanol Blends on Engine Performance and Exhaust Emissions in a Spark Ignition Engine
}

\author{
Savaş Yelbey ${ }^{1^{*}}$ (D) Murat Ciniviz $^{2}$ (D) \\ 'Yozgat Bozok University, Vocational School of Technical Sciences, Department of Automotive Technology, Yozgat, Turkey \\ ${ }^{2}$ Selcuk University, Faculty of Technology, Department of Mechanical Engineering, Konya, Turkey
}

\begin{abstract}
In this study; 95 octane unleaded gasoline and bioethanol were tested as fuel in a spark-ignition engine by blending bioethanol with gasoline in certain proportions $(2 \%, 4 \%, 6 \%, 8 \%, 10 \%)$. Tests were carried out at five different engine loads for a constant engine speed of $2500 \mathrm{rpm}$. The variations in engine performance parameters (engine torque, engine power, brake thermal efficiency, brake specific fuel consumption, brake specific energy consumption) and exhaust emissions (exhaust gas temperature, $\mathrm{HC}, \mathrm{CO}, \mathrm{CO}_{2}$ and $\mathrm{O}_{2}$ ) were investigated on the basis of test fuel and engine load. According to the test results, with the increase of bioethanol ratio in the blend, brake specific fuel consumption values increased by $9.71 \%$ and brake thermal efficiency values decreased by approximately $4.97 \%$ compared to gasoline. There was decrease up to $35.56 \%$ and up to $23.77 \%$ in $\mathrm{HC}$ and CO emissions respectively, and an increase by $6.01 \%$ in $\mathrm{CO}_{2}$ emissions with bioethanol addition.
\end{abstract}

Keywords: Gasoline, bioethanol, exhaust emission, engine performance

\section{INTRODUCTION}

Energy is one of the fundamental and driving needs of a countries economic and social development. In this respect, "Energy Security" is a vital element of economic and national security. It is an indispensable input for almost all the processes necessary to sustain our social life and used in sub-sectors such as industry, transportation, housing and commercial. Today, $86 \%$ of the energy consumption is met from fossil sources such as oil, natural gas and coal in the world. Oil, as the main energy source of the transportation sector, has the largest share in the world's primary energy consumption. Turkey is one of the significant energy consumers with its emerging economy. Oil ranks first with the rate of $31 \%$ in primary energy demand which is equal to 136.2 MTEP in 2016 and it is followed by natural gas and coal. When the distribution of Turkey's primary energy demand was examined, it was observed as follows: $25 \%$ of it in industry, $24 \%$ of it in housing and service industry, $23 \%$ of it in electricity generation, $20 \%$ of it in transportation industry [1].

The fact that most of the energy demand is met from petroleum and its derivatives, however, the depletion of oil reserves, directs humanity to long-lasting, no consumable resources. Considering the environmental impacts caused by petroleum fuels such as carbon dioxide and greenhouse gas emissions and acid rain associated with them, global warming and climate changes, the importance of alternative energy increases. The use of alternative energy sources is also inevitable for Turkey which meet the oil demand with importing $89 \%$ of it $[1,2]$.

The petroleum crisis at 1970s leaded many countries to searching of alternative fuels, thus the use of ethanol as a fuel has been brought to the agenda, and studies on fuel ethanol have increased rapidly day by day. In the early days, corn was used as the raw material of ethanol production because of its easy production and its ability to be converted to a high rate to alcohol $[3,4]$. Today, renewable products such as sugar cane, sugar beet and cassava are the most important raw materials of ethanol. Bioethanol has same molecule with ethanol as chemically. The difference of bioethanol from ethanol is that it produces from biological feedstocks via fermentation methods. Therefore, it called bioethanol. The ethanol produces from petrochemical feedsotcks such as ethylene, calcium carbide, coal, natural gas via catalytic hydration [5-7].

Since bioethanol has similar fuel properties with gasoline, it can be used both directly and mixed with gasoline in spark plug ignition engines. In addition, the higher octane number of ethanol allows spark ignition engines to run at higher 
compression ratios. Many European countries with primarily the world's largest bioethanol producers USA and Brazil, also use bioethanol as fuel [8].

The use of bioethanol as fuel causes a decrease in engine performance due to its low calorific value [9]. However, there are also many studies showing that exhaust emissions of spark ignition engines reduce by increasing the combustion quality thanks to the oxygen content of bioethanol $[10,11]$. It is even stated that, thanks to its oxygen content, it increases the volumetric efficiency and thus causes an increase in the thermal efficiency values from time to time $[12,13]$.

Altun, Öztop [14] investigated the effects of ethanol and methanol addition $(5,10 \%$ by volume) to unleaded gasoline on performance and exhaust emissions of a spark-ignition engine. They performed their experiments at different engine speeds varied from 1000 to $4000 \mathrm{rpm}$ for full throttle position. It was observed decrease in brake thermal efficiency, $\mathrm{CO}$ and $\mathrm{HC}$ emissions, while brake specific fuel consumption increased with alcohol addiction. It stated that researchers achieved best results in the case of the engine being fueled blend contain 10\% methanol or ethanol at current engine design. Balki, Sayin [15] examined the use of alcohols (ethanol and methanol) on performance, emission and combustion characteristics of a single-cylinder engine by comparing unleaded gasoline. They performed the experiments at variable engine speeds for full open throttle. As a result, they stated that the use of alcohol fuels increases engine torque, instantaneous specific fuel consumption, thermal efficiency and combustion efficiency. In the case of engine being operated with alcohols, the cylinder gas pressure and heat release rate had already occurred before. It also reported that $\mathrm{CO}_{2}$ emission increased while $\mathrm{HC}, \mathrm{CO}$ and NOx emissions decreased. Najafi, Ghobadian [16] have tested the engine with E5, E7.5, E10, E12.5 and E15 gasoline-ethanol blends to investigate the performance and emission behavior of a four-cylinder, four-stroke spark ignition engine. They stated that usage of ethanol in blend increased brake torque, and brake power and improved the exhaust emissions but it decreased brake specific fuel consumption. The optimum values are obtained when engine operated at 3000 rpm engine speed with E10. Özsezen [17] used a single-cylinder spark-ignition engine with a compression ratio of $8 / 1$ in their experimental study. Within the context of study, tests were performed at 1000, 1500, 2000 and 2500 rpm in a spark-ignition engine fueled with gasoline-ethanol (E5 and E10) blends to examine engine performance and exhaust emissions. The results of study indicated that $\mathrm{CO}$ and unburned $\mathrm{HC}$ emissions were reduced but $\mathrm{CO}_{2}$ and $\mathrm{NOx}$ emissions were increased when the test engine was run with gasoline-ethanol blends. In addition, it is stated that the air-fuel ratio increased with increasing ratio of ethanol in blended fuels. Deng, Chen [18] carried out their tests in a single-cylinder, variable compression ratio spark-ignition engine operated with unleaded gasoline, pure ethanol and their blends (10\% and 20\%). Test conditions are as follows: five different compression ratios by of $4 / 1,5.5 / 1,7 / 1,8.5 / 1$, $10 / 1$ and full open throttle. It was found that brake average effective pressure, brake thermal efficiency and brake specific fuel consumption were higher when the fuel is gasoline-ethanol blend. They also stated that it was obtained better results for gasoline-ethanol blends compared with pure gasoline with regard to exhaust emissions. They also added the results that NOx emissions became more unstable as the compression ratio changed during the tests.

Bioethanol is a renewable alcohol with high energy value that can be produced with local sources. It is used as alternative fuel in spark plug ignition engines due to the high octane number. In this study, the effects of up to $10 \%$ bioethanol addition to gasoline on performance and emission parameters were analyzed step by step. The engine torque, power, brake specific fuel consumption, brake specific energy consumption and brake thermal efficiency values were investigated as engine performance parameters, and $\mathrm{CO}, \mathrm{HC}, \mathrm{CO}_{2}, \mathrm{O}_{2}$ and exhaust gas temperature values were investigated as exhaust emission characteristics. The obtained results were compared with gasoline, and have been presented as graphically.

\section{MATERIAL AND METHOD}

The test setup consisting of universal drive and brake unit, display panel, fuel tank, measuring tube for fuel consumption, temperature measuring device, pressure measuring device, speed measuring device, emission measuring device and a gasoline engine is shown in Figure 1. Technical specifications of the single cylinder, four stroke and air-cooled internal combustion engine are given in Table 1.

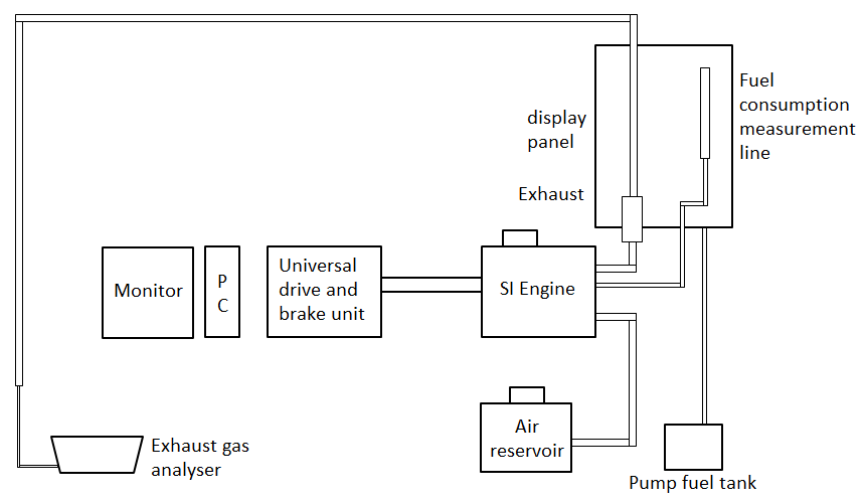

Figure 1. Experimental setup

Table 1. Specification of test engine

\begin{tabular}{|l|l|}
\hline \multicolumn{1}{|c|}{ Engine Brand } & \multicolumn{1}{c|}{ GUNT CT152 } \\
\hline Engine type & Four stroke, with carburettor \\
Cylinder number & 1 \\
Bore $x$ Stroke, $(\mathrm{mm} \times \mathrm{mm})$ & $65.1 \times 44.4$ \\
Cooling system & Air cooled \\
Compression ratio & $7: 1$ \\
Maximum engine power & $1.2 \mathrm{~kW}$ \\
Maximum engine torque & $4.5 \mathrm{Nm}$ \\
Ignition advance & $25^{\circ} \mathrm{BTDC}$ \\
\hline
\end{tabular}

Measurement ranges and accuracies of Mobydic 5000 portable gas analyzer used to measure exhaust emissions are given in Table 2. 
Table 2. Specifications of the Mobydic 5000 portable gas analyzer

\begin{tabular}{|l|c|c|}
\hline Measurement module & Ranges & Accuracies \\
\hline $\mathrm{CO}(\%$ vol $)$ & $0-10$ & 0.01 \\
\hline $\mathrm{CO}_{2}(\%$ vol $)$ & $0-20$ & 0.01 \\
\hline $\mathrm{HC}(\mathrm{ppm}$ vol $)$ & $0-2000$ & 1 \\
\hline $\mathrm{NO}_{\mathrm{x}}(\%$ vol $)$ & $0-5000$ & 1 \\
\hline Lambda & $0-5$ & 0.001 \\
\hline
\end{tabular}

In the experiments, 95 octane unleaded gasoline purchased from one of the gas stations and bioethanol obtained supplied from Konya Sugar Factory were used to form fuel blends, contents of which are as follows. In Table 3, some physical properties of test fuels are given.

E0: $100 \%$ unleaded gasoline

E2: $\quad 98 \%$ unleaded gasoline - 2\% bioethanol

E4: $\quad 96 \%$ unleaded gasoline - 4\% bioethanol

E6: $94 \%$ unleaded gasoline - $6 \%$ bioethanol

E8: $92 \%$ unleaded gasoline - $8 \%$ bioethanol

E10: $90 \%$ unleaded gasoline - 10\% bioethanol

\begin{tabular}{|c|c|c|c|c|}
\hline Test fuels & $\begin{array}{c}\text { Density } \\
\left(15^{\circ} \mathrm{C}-\mathrm{g} / \mathrm{cm}^{3}\right)\end{array}$ & $\begin{array}{c}\text { Lower } \\
\text { heating value } \\
(\mathrm{MJ} / \mathrm{kg})\end{array}$ & $\begin{array}{c}\text { Kinematic } \\
\text { viscosity } \\
\left(40^{\circ} \mathrm{C}-\mathrm{mm}^{2} / \mathrm{s}\right)\end{array}$ & $\begin{array}{c}\text { Water } \\
\text { content } \\
\text { (ppm) }\end{array}$ \\
\hline $\begin{array}{c}\text { Bioethanol } \\
\text { (E100) }\end{array}$ & 0.78820 & 26.694 & 1.2 & 1093.4 \\
\hline Gasoline (E0) & 0.72926 & 42.582 & 0.566081 & - \\
\hline E2 & 0.73198 & 42.131 & 0.576054 & - \\
\hline E4 & 0.73354 & 41.899 & 0.587451 & - \\
\hline E6 & 0.73557 & 41.732 & 0.597899 & - \\
\hline E8 & 0.73594 & 41.235 & 0.607872 & - \\
\hline E10 & 0.73809 & 40.901 & 0.617845 & - \\
\hline
\end{tabular}

\section{RESULTS}

\subsection{Engine Performance Parameters}

Figure 2 shows changes of max torque and max power values for test fuels. The lower of calorific value of bioethanol caused a decrease both torque and power values. This decrement increased with increment of bioethanol ratio in blends. The highest decrement values have obtained by $5.77 \%$ for torque and by 6.25 for power with E10 fuel.

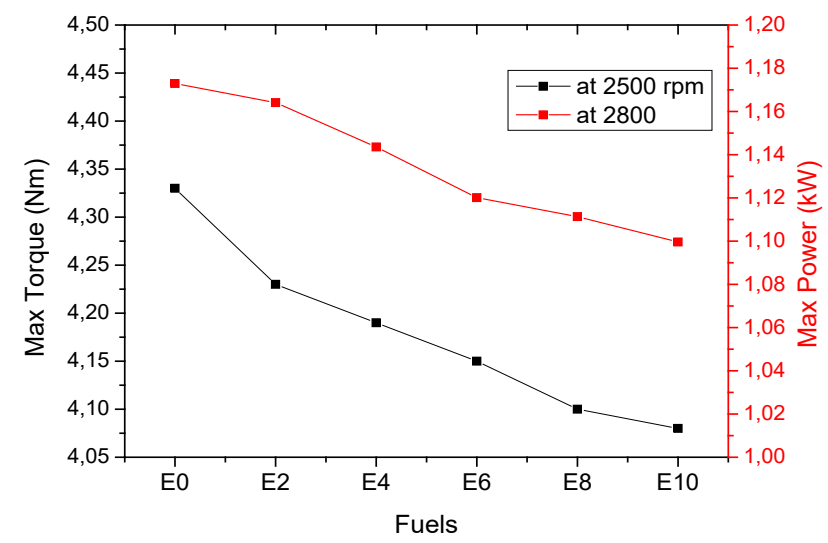

Figure 2. Maximum torque and maximum power ratings of test fuels

Brake specific fuel consumption (BSFC) is the amount of fuel, used by the engine to obtain brake power. BSFC values obtained during the tests performed at five engine loads and constant engine speed of $2500 \mathrm{rpm}$, maximum torque speed, are shown in Figure 3. As a result of the experiments, the lowest BSFC values were obtained at $2.5 \mathrm{Nm}$ engine load for all test fuels. When the data obtained for all engine loads were examined, the lowest BSFC value was obtained as $525.593 \mathrm{~g} / \mathrm{kWh}$ with gasoline. With the increase in bioethanol ratios in the blends, this value increased to $589.765 \mathrm{~g} /$ kWh with E10 fuel. The highest BSFC values for gasoline, E2 and E4 fuels are obtained at $4 \mathrm{Nm}$ engine load, while the BSFC values at $4 \mathrm{Nm}$ were lower than those at $2 \mathrm{Nm}$ for other test fuels. This can be explained by the fact that the ideal operating range of the engine is around $2.5 \mathrm{Nm}-3 \mathrm{Nm}$. Load average-BSFC values are higher approximately $2.27 \%$, 3.65\%, 6.26\%, 7.91\% and 9.70\% for E2, E4, E6, E8 and E10 respectively than that of E0. The bioethanol has lower calorific value (about 37.31\%) than gasoline. This caused the lower thermal value of the E10 fuel to drop to approximately $4 \%$. Therefore, BSFC values for bioethanol added fuels are higher than gasoline. In the literature, there are studies showing that addition of bioethanol increases BSFC unless any modification is made in the engine for similar reasons $[19,20]$.

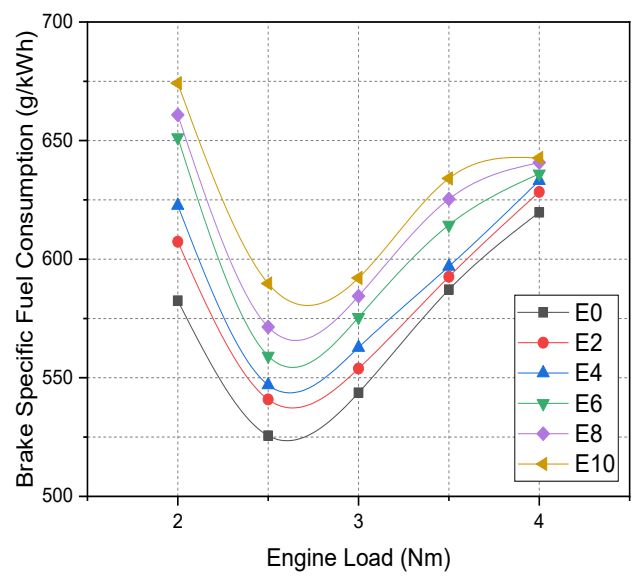

Figure 3. Variation of BSFC with engine load

Brake specific energy consumption (BSEC) is the amount of energy consumed by engine to generate unit power. The variation of BSEC with engine load and bioethanol content are shown in Figure 4. As a result of the experiments, the lowest BSEC values for all test fuels were obtained at $2.5 \mathrm{Nm}$ engine load. When the data obtained for all engine loads were examined, the lowest BSEC value was obtained with gasoline as $22.381 \mathrm{MJ} / \mathrm{kWh}$, this value reached up to $24.122 \mathrm{MJ} / \mathrm{kWh}$ for E10 fuel for the same engine load value by increasing with bioethanol rate. For gasoline, E2 and E4 fuels, the highest BSEC were obtained at $4 \mathrm{Nm}$ engine load, and for other fuels BSEC are lower at $4 \mathrm{Nm}$ than that of $2 \mathrm{Nm}$. This can be explained by the fact that the energy per unit power is lower in the range of $2.5 \mathrm{Nm}$ to $3 \mathrm{Nm}$ engine loads. For average engine loads, the increase in BSEC are approximately $1.18 \%$, 1.99\%, 4.14\%, 4.49\% and 5.37\% for E2, E4, E6, E8 and E10 respectively with respect to gasoline. Both the increase in fuel consumption and decrease in calorific value with bioethanol addition have led to an increase in the BSEC. Zhuang and Hong [21] also reported in their studies that due to the low calorific value of bioethanol, the amount of heat ener- 


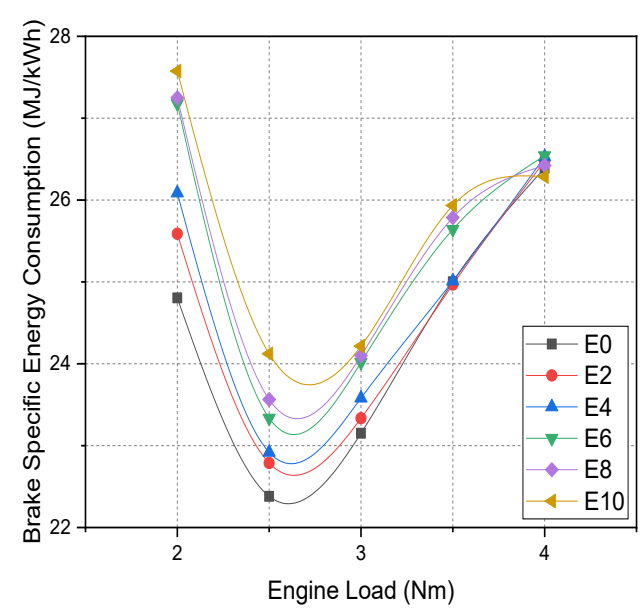

Figure 4. Variation of BSEC with engine load

gy released in the cylinder decreased and fuel consumption increased with bioethanol usage, and therefore BSEC values increased.

Figure 5 shows the variation in brake thermal efficiency (BTE), which is an expression of conversion ratio of fuel energy to brake power. As a result of the experiments, the highest BTE values were obtained with gasoline and it was observed that the BTE values decreased with increasing bioethanol ratio in the blend. For all test fuels, maximum BTE values were obtained at $2.5 \mathrm{Nm}$ engine load i.e. $16.085 \%$ for gasoline and 14.924\% for E10 fuel. After $2.5 \mathrm{Nm}$ engine load, BTE values have started to decrease with the increase in friction losses and the amount of fuel consumed. With bioethanol usage, the decrease in BTE are approximately 1.16\%, $1.92 \%, 3.90 \%, 4.21 \%$ and $4.97 \%$ for E2, E4, E6, E8 and E10 respectively. As a result of the decrease in the thermal value of the addition of bioethanol, it requires more fuel consumption per unit time in order to obtain an equal amount of brake power under the same operating conditions of engine. Due to the fact that the amount of fuel taken into the cylinders in one cycle is almost the same for all test fuels and lower heating values of the blended fuels, the amount of energy generated in the cylinder during combustion decreases, thus reduce the engine output power. Since this decreasing engine output power value is obtained with the same amount of fuel, the BTE values of the engine are also decreased in the calculations. In the literature, some researchers have reported that due to the high evaporation temperature of bioethanol in the combustion chamber cannot be achieved in the homogeneity of the mixture so the use of bioethanol decreased BTE values [22, 23].

\subsection{Exhaust Emission Parameters}

The exhaust gas temperature (EGT) is an important parameter in the interpretation of exhaust emission parameters and the quality of combustion within the cylinder. The variation in the EGT depending on the engine load are shown in Figure 6. By adding bioethanol to gasoline, EGT values increased up to $473.2{ }^{\circ} \mathrm{C}$. It is the result of increasing combustion efficiency affected positively by oxygen content of bioethanol. However, Topgül [24] stated that addition of ethanol in ra-

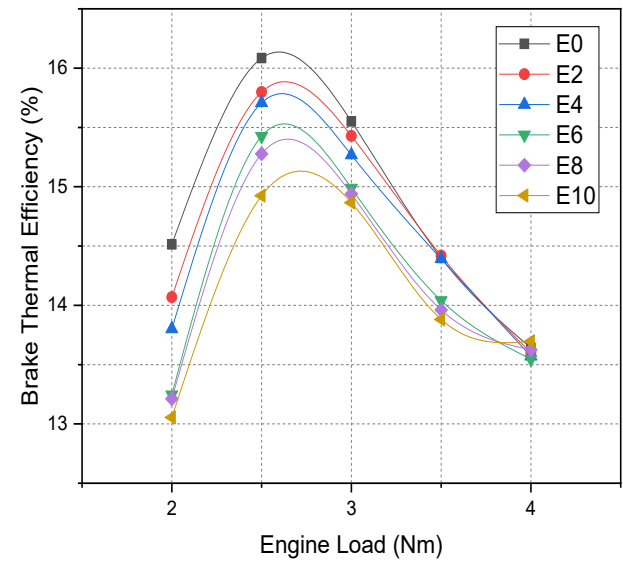

Figure 5. Variation of BTE with engine load

tios above $10 \%$ ethanol undermines the homogeneity of the mixture by the effect of high evaporation heat of it. It is also reported that increased oxygen content of the blend reduced the amount of hydrocarbon and increased combustion rate decreased the end-combustion temperature. According to the results of the experiment, with the use of bioethanol, the EGT values of E2, E4, E6, E8 and E10 fuels increased by $0.66 \%, 1.83 \%, 3.02 \%, 3.36 \%$ and $3.70 \%$ on average. With the increase in engine load, more fuel enters to the cylinder at the same speed, but the time required to burn it cannot be provided. Therefore, the fuel does not burn completely and the EGT decreases.

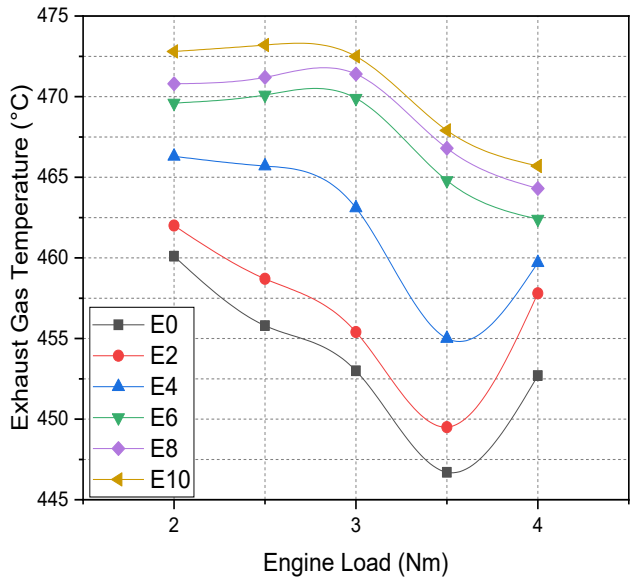

Figure 6. Variation of EGT with engine load

With the combustion of hydrocarbon-based engine fuels, $\mathrm{H}_{2} \mathrm{O}_{\text {gaz }}$ produce as usual. However, if sufficient oxygen is not taken into the cylinder, the $\mathrm{H}$ atom cannot find enough $\mathrm{O}$ atoms for this reaction and generates $\mathrm{HC}$ emissions. Bioethanol allows the $\mathrm{H}$ atoms in the fuel to break off from the $\mathrm{C}$ atoms during combustion and react with oxygen to burn. Thus, the combustion approaches the completion. As shown in Figure 7, $\mathrm{HC}$ emission values decreased to 172 ppm with the use of bioethanol. In addition, the increase in EGT is another factor in reducing $\mathrm{HC}$ emissions. Increased $\mathrm{HC}$ emissions due to engine load are the result of reduced EGT as engine load increases. While the lowest HC emission values were obtained with E10 fuel, as the bioethanol content in the mixture increased, $\mathrm{HC}$ emission values decreased by $5.33 \%, 11.16 \%, 22.70 \%, 27.70 \%$ and $35.56 \%$ with 
E2, E4, E6, E8 and E10 fuels on average. Similar results have been reported in the literature showing that bioethanol reduces HC emissions [25, 26].

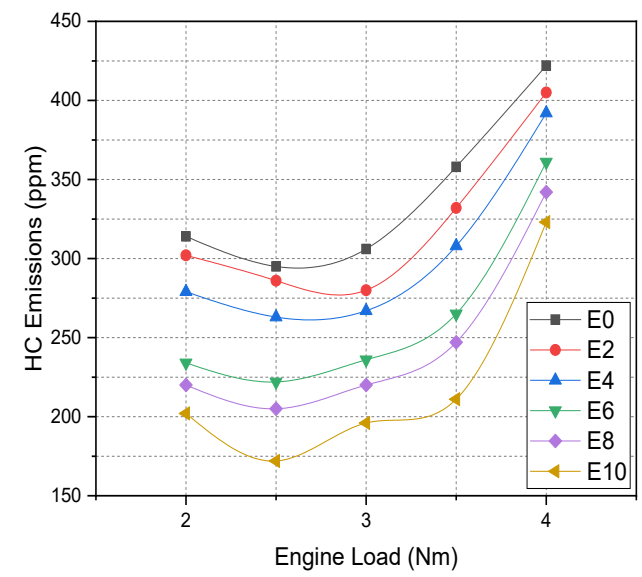

Figure 7. Variation of $\mathrm{HC}$ emission with engine load

Low oxygen intake to the cylinders prevents the complete combustion of the fuel and releases $\mathrm{CO}$ gas from the exhaust instead of $\mathrm{CO}_{2}$, usual combustion product. The increase in engine load requires more fuel to burn in the same duration. The greater amount of fuel in the combustion chamber cannot burn faster, $\mathrm{CO}$ emissions increase with increasing engine load. Figure 8 shows variation of $\mathrm{CO}$ emission with engine load. Bioethanol supply $\mathrm{O}_{2}$ to react $\mathrm{CO}_{2}$ during combustion, resulting in a reduction in $\mathrm{CO}$ emissions. For example, $\mathrm{CO}$ emissions were reduced by up to $2.29 \%$ with E10 fuel compared to gasoline. Load averaged-CO emission values decreased by $7.86 \%, 11.71 \%, 22.72 \%, 23.77 \%$ and $26.04 \%$ on average with E2, E4, E6, E8 and E10 fuels. It has been reported by other researchers that bioethanol reduces $\mathrm{CO}$ emissions as it causes the fuel burn completely [10, 27, 28].

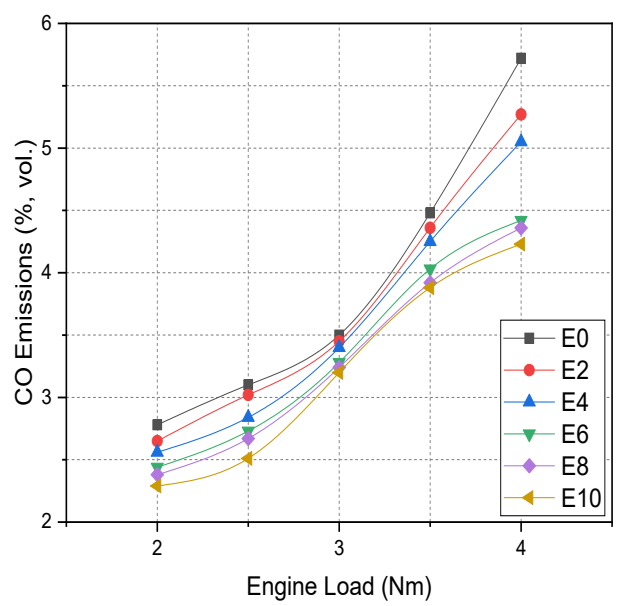

Figure 8. Variation of $\mathrm{CO}$ emission with engine load

Figure 9 shows the variation of $\mathrm{CO}_{2}$ emission depending on engine load. Bioethanol has small amount of $\mathrm{C}$ atoms compared to gasoline. It improves the combustion efficiency, resulting as a reduction in $\mathrm{CO}_{2}$ emissions by $6.01 \%$. However, the lowest $\mathrm{CO}_{2}$ emission values were obtained at $3.5 \mathrm{Nm}$ engine load, where combustion efficiency was close to ideal, and $\mathrm{CO}_{2}$ emissions were increased due to the decrease in the amount of fuel taken into the cylinder at lower engine loads and the homogeneity of the mixture due to the high evaporation temperature of bioethanol. In addition, at higher engine loads, the time for the fuel to burn was shortened, thus causing the fuel to not burn completely, causing $\mathrm{CO}$ emissions. These results are similar to previous studies in the literature [15, 29-31].

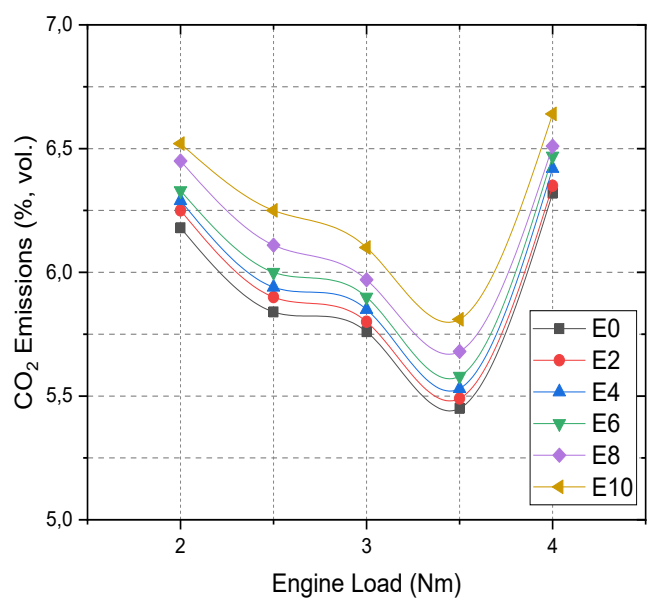

Figure 9. Variation of $\mathrm{CO}_{2}$ emission with engine load

Variations of $\mathrm{O}_{2}$ emission at different engine load values are given in Figure 10. The $\mathrm{O}_{2}$ concentration depends on the oxygen/fuel ratio in the cylinders. Bioethanol contains oxygen in its chemical structure and increases the oxygen concentration of the mixture fuels made with gasoline. In this experimental study, $\mathrm{O}_{2}$ emission values of blended fuels were higher than gasoline. The highest $\mathrm{O}_{2}$ emission for all test fuels are found for E10 fuel as $12.03 \%$. The variation in engine load had no significant effect on the amount of $\mathrm{O}_{2}$ in the exhaust gas. Compared to gasoline, $\mathrm{O}_{2}$ emission values of E2, E4, E6, E8 and E10 fuels are higher as by 1.96\%, 2.48\%, $11.43 \%, 12.03 \%$ and $22.39 \%$ respectively.

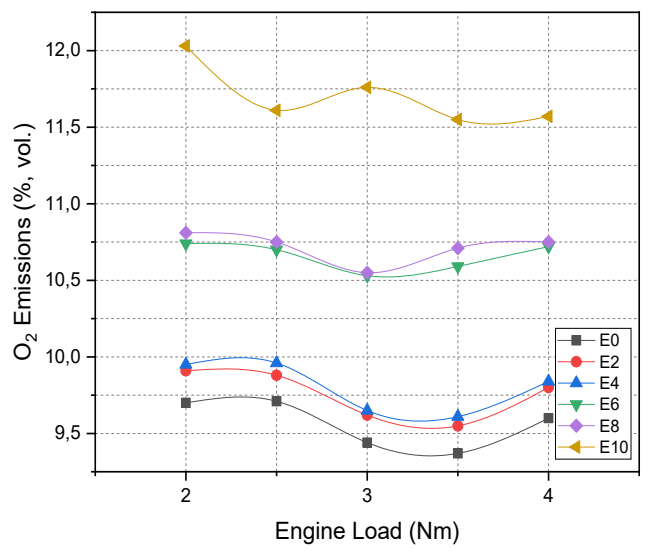

Figure 10. Variation of $\mathrm{O}_{2}$ emission with engine load

\section{CONCLUSION}

In this study, engine performance and exhaust emission of a single cylinder spark ignition engine used gasoline-bioethanol blends were examined and the results were presented as follows.

- Although bioethanol produced from sugar beet has 
similar fuel characteristics with gasoline, the lower heating value of it stands out as the most important parameter adversely affecting engine performance.

- Due to the fact that it has lower thermal value than gasoline and higher combustion rate due to oxygen content, bioethanol has a negative effect on performance parameters by decreasing in the effective pressure affecting the piston surface. The increase in bioethanol ratio in the blends resulted in an increase in the BSFC and BSEC values up to $9.70 \%$ and $5.37 \%$ on average, while the BTE values decreased by of $4.97 \%$, respectively.

- Blending gasoline with bioethanol up to $10 \%$ improves the combustion efficiency, thus an increase in exhaust temperature values observed up to $3.7 \%$ compared to gasoline. It indicates that the fuel can burn more completely, thus it also reduce $\mathrm{HC}$ emissions.

- Bioethanol causes cleaner combustion and reduces harmful exhaust gases. Oxygen in bioethanol content reacted with $\mathrm{H}$ and $\mathrm{C}$ atoms in hydrocarbon based fuels during combustion, so it causing less $\mathrm{HC}$ and CO emissions by of $35.56 \%$ and $26.04 \%$, respectively. In addition, it has a reduction in $\mathrm{CO}_{2}$ emissions up to $6.01 \%$ as it has a lower amount of $\mathrm{C}$ atoms than gasoline.

In conclusion, although the addition of bioethanol to gasoline affects the engine performance parameters negatively, it is seen that this negative effect is at most $9.70 \%$. Compared to it with improvement in exhaust emission parameters by of $35.56 \%$, bioethanol is a convenient fuel. Furthermore, the fact that addition bioethanol by of $10 \%$ to fuel can be used without any change in engine operating parameters indicates that legal limit (4\%) for addition bioethanol to gasoline can be easily increased in our country.

\section{ACKNOWLEDGMENT}

This study is produced from master's thesis of Savaş Yelbey. Appreciations to Selcuk University Scientific Research Projects Unit (Project No: 18201146) for its support.

\section{REFERENCES}

[1] TPAOGM (2018). Crude oil and natural gas sector report for 2017. General Directorate of Turkey Petroleum Corporation.

[2] Sezgin, B., Bilen, K., Çelik, V. (2013). Modification of a Diesel Engine to Natural Gas and Experimental Analysis of Modified Engine Performance and Exhaust Emission. Engineer \& the Machinery Magazine, 54(642): 41-51.

[3] Illker, Ö., Ciniviz, M. (2012). Investigation On Vehicle Using Gasoline-Bioethanol Blended Fuels. International Journal of Automotive Engineering and Technologies, 1(2): 32-39.

[4] Niphadkar, S., Bagade, P., Ahmed, S. (2018). Bioethanol production: insight into past, present and future perspectives. Biofuels, 9(2): 229-238.
[5] Lavanya, A. K., Sharma, A., Choudhary, S. B., Sharma, H. K., Nain, P. K. S., Singh, S., Nain, L. (2019). Mesta (Hibiscus spp.)-a potential feedstock for bioethanol production. Energy Sources, Part A: Recovery, Utilization, and Environmental Effects, 1-14.

[6] Melikoglu, M., Albostan, A. (2011). Bioethanol production and potential of Turkey. Journal of the Faculty of Engineering and Architecture of Gazi University, 26(1): 151-160.

[7] Örs, I. (2020). Experimental investigation of the cetane improver and bioethanol addition for the use of waste cooking oil biodiesel as an alternative fuel in diesel engines. Journal of the Brazilian Society of Mechanical Sciences and Engineering, 42(4): 1-14. doi: $10.1007 / s 40430-020-2270-1$

[8] Costa, R. C., Sodré, J. R. (2010). Hydrous ethanol vs. gasoline-ethanol blend: Engine performance and emissions. Fuel, 89(2): 287-293.

[9] Renzi, M., Bietresato, M., \& Mazzetto, F. (2016). An experimental evaluation of the performance of a SI internal combustion engine for agricultural purposes fuelled with different bioethanol blends. Energy, 115: 1069-1080.

[10] Balki, M.K., Sayin, C. (2014). The effect of compression ratio on the performance, emissions and combustion of an SI (spark ignition) engine fueled with pure ethanol, methanol and unleaded gasoline. Energy, 71: 194-201.

[11] Celik, M.B. (2008). Experimental determination of suitable ethanolgasoline blend rate at high compression ratio for gasoline engine. Applied Thermal Engineering, 28(5-6): 396-404.

[12] Qi, D., Lee, C.-F. (2016). Combustion and emissions behaviour for ethanol-gasoline-blended fuels in a multipoint electronic fuel injection engine. International Journal of Sustainable Energy, 35(4): 323-338.

[13] Schifter, I., Diaz, L., Rodriguez, R., Gómez, J. P., Gonzalez, U. (2011). Combustion and emissions behavior for ethanol-gasoline blends in a single cylinder engine. Fuel, 90(12): 3586-3592.

[14] Altun, Ş., Öztop, H., Öner, C., Varol, Y. (2013). Exhaust emissions of methanol and ethanol-unleaded gasoline blends in a spark-ignition engine. Thermal Science, 17(1): 291-297. doi:10.2298/tsci111207034a

[15] Balki, M. K., Sayin, C., Canakci, M. (2014). The effect of different alcohol fuels on the performance, emission and combustion characteristics of a gasoline engine. Fuel, 115: 901-906. doi:10.1016/j. fuel.2012.09.020

[16] Najafi, G., Ghobadian, B., Yusaf, T., Safieddin Ardebili, S. M., Mamat, R. (2015). Optimization of performance and exhaust emission parameters of a SI (spark ignition) engine with gasoline-ethanol blended fuels using response surface methodology. Energy, 90: 18151829. doi:10.1016/j.energy.2015.07.004

[17] Özsezen, A.N. (2016). Evaluating Environmental Effects of Bioethanol-Gasoline Blends in Use a SI Engine. Uluslararası Yakıtlar, Yanma ve Yangın Dergisi, (4): 36-41.

[18] Deng, X., Chen, Z., Wang, X., Zhen, H., Xie, R. (2018). Exhaust noise, performance and emission characteristics of spark ignition engine fuelled with pure gasoline and hydrous ethanol gasoline blends. Case Studies in Thermal Engineering, 12: 55-63. doi:10.1016/j.csite.2018.02.004

[19] Doğan, B., Erol, D., Yaman, H., Kodanli, E. (2017). The effect of ethanol-gasoline blends on performance and exhaust emissions of a spark ignition engine through exergy analysis. Applied Thermal Engineering, 120: 433-443. doi:10.1016/j.applthermaleng.2017.04.012 
[20] Koç, M., Sekmen, Y., Topgül, T., \& Yücesu, H. S. (2009). The effects of ethanol-unleaded gasoline blends on engine performance and exhaust emissions in a spark-ignition engine. Renewable Energy, 34(10): 2101-2106. doi:10.1016/j.renene.2009.01.018

[21] Zhuang, Y., Hong, G. (2013). Primary investigation to leveraging effect of using ethanol fuel on reducing gasoline fuel consumption. Fuel, 105: 425-431. doi:10.1016/j.fuel.2012.09.013

[22] Kamil, M., Nazzal, I.T. (2016). Performance Evaluation of Spark Ignited Engine Fueled with Gasoline-Ethanol-Methanol Blends. Journal of Energy and Power Engineering, 10(6). doi:10.17265/1934$8975 / 2016.06 .002$

[23] Phuangwongtrakul, S., Wechsatol, W., Sethaput, T., Suktang, K., Wongwises, S. (2016). Experimental study on sparking ignition engine performance for optimal mixing ratio of ethanol-gasoline blended fuels. Applied Thermal Engineering, 100: 869-879. doi:10.1016/j.applthermaleng.2016.02.084

[24] Topgül, T., (2006). The investigation of optimum working parameters of spark ignition engines using ethyl alcohol-gasoline blend. Gazi University Graduate School of Natural and Applied Sciences.

[25] Elfasakhany, A., (2015). Investigations on the effects of ethanolmethanol-gasoline blends in a spark-ignition engine: performance and emissions analysis. Engineering Science and Technology, an International Journal, 18(4): 713-719.

[26] Hasan, A. O., Al-Rawashdeh, H., Al-Muhtaseb, A. H., Abu-jrai Ahmad, Ahmad, R., Zeaiter, J. (2018). Impact of changing combustion chamber geometry on emissions, and combustion characteristics of a single cylinder SI (spark ignition) engine fueled with ethanol/ gasoline blends. Fuel, 231: 197-203. doi:10.1016/j.fuel.2018.05.045

[27] Kasmuri, N. H., Kamarudin, S. K., Abdullah, S. R. S., Hasan, H. A., Som, A. M. (2017). Process system engineering aspect of bio-alcohol fuel production from biomass via pyrolysis: An overview. Renewable and Sustainable Energy Reviews, 79: 914-923. doi:10.1016/j. rser.2017.05.182

[28] Wang, X., Chen, Z., Ni, J., Liu, S., Zhou, H. (2015). The effects of hydrous ethanol gasoline on combustion and emission characteristics of a port injection gasoline engine. Case Studies in Thermal Engineering, 6: 147-154. doi:10.1016/j.csite.2015.09.007

[29] Canakci, M., Ozsezen, A. N., Alptekin, E., Eyidogan, M. (2013). Impact of alcohol-gasoline fuel blends on the exhaust emission of an SI engine. Renewable Energy, 52: 111-117. doi:10.1016/j.renene.2012.09.062

[30] Costagliola, M. A., Prati, M. V., Florio, S., Scorletti, P., Terna, D., lodice, P., ... Senatore, A. (2016). Performances and emissions of a 4-stroke motorcycle fuelled with ethanol/gasoline blends. Fuel, 183: 470477. doi:10.1016/j.fuel.2016.06.105

[31] Iodice, P., Langella, G., Amoresano, A. (2018). Ethanol in gasoline fuel blends: Effect on fuel consumption and engine out emissions of SI engines in cold operating conditions. Applied Thermal Engineering, 130: 1081-1089. doi:10.1016/j.applthermaleng.2017.11.090 